\title{
Population structure and reproduction of a migratory fish Leporinus piau (Characiformes: Anostomidae) in a semiarid tropical reservoir, Brazil
}

\author{
Darlan Dantas Alves de Araújo, Jônnata Fernandes de Oliveira, Rodrigo Silva da Costa \& \\ José Luís Costa Novaes* \\ Departamento de Ciências Animais, Universidade Federal Rural do Semi-Árido. Av. Francisco Mota, 572, Costa \\ e Silva, Mossoró (RN),Brasil; darlandantas@ufersa.edu.br, jonnata_bio@hotmail.com,rdgcosta@ufersa.edu.br, \\ novaes@ufersa.edu.br \\ * Correspondence
}

\section{Received 23-XI-2015. Corrected 06-VI-2016. Accepted 05-VII-2016.}

\begin{abstract}
Migratory fishes have been seriously impacted by the building of reservoirs and because of the negative effects of these projects such as the interruption of migratory routes, reduction or elimination of spawning/ feeding areas, and initial development can influence the population structure the migratory fishes, resulting in reduction in abundance. Leporinus piau is migratory fish widely distributed in the watersheds of the Brazilian semiarid and it is of importance for artisanal and sport fishing. The goal of the study was to evaluate the population structure and reproductive dynamics of the migratory species Leporinus piau in the Pau dos Ferros Reservoir, which is located in the semiarid region of Brazil. The CPUE, length structure, length-weight relationship, length at first maturity, sex ratio, gonad development and IGS were analyzed. Collections were performed quarterly between February 2011 and November 2012 using gillnets. The captured fish were counted; the standard length $(\mathrm{cm})$ and total weight $(\mathrm{g})$ were measured, and dissected to determine the sex and gonad maturity stage. The rainfall and reservoir water levels were recorded, and their correlations with the reproductive period and CPUE were analyzed. A total 549 individuals were captured. The average CPUE varied between 0.0259 individuals $/ \mathrm{m}^{2 *} \mathrm{~h}\left(\right.$ May/2011) and 0.0008 individuals $/ \mathrm{m}^{2 *} \mathrm{~h}$ (August $\left./ 2012\right)$, and significant differences were observed; however, significant correlations were not observed between rainfall and reservoir levels. The standard length varied between $5.9 \mathrm{~cm}$ and $20.7 \mathrm{~cm}$, and the weight varied between $4.16 \mathrm{~g}$ and $271.5 \mathrm{~g}$. A histogram analysis revealed that the $5-10 \mathrm{~cm}$ standard length class was the most abundant for juveniles and that the 10-15 $\mathrm{cm}$ class was the most abundant for adult females and males. The weight-length relationship was best fit by the equation $\log _{10} \mathrm{Wt}=-1.57711+3.00707 \log _{10} \mathrm{Ls}$, and the species presented isometric growth. The estimated length at first maturity was $12.76 \mathrm{~cm}$. A total of 148 males and 82 females were collected (1.81:1, M:F), and these values were significantly different. The highest GSI was observed in February 2011 for both females (10.69) and males (5.72), and the GSI was significantly and positively correlated with rainfall. We concluded that the L. piau population is established in the reservoir and found that its reproduction period occurred during the rainy season between February and May. Rev. Biol. Trop. 64 (4): 1369-1381. Epub 2016 December 01.
\end{abstract}

Key words: dam, reproductive period, length at first maturity, CPUE, conservation, piau.

Semiarid regions in Brazil exhibit river seasonality and a small hydrological network relative to other regions of Brazil; for this condition, a water resources policy was established for Brazilian semiarid areas, based on water accumulation during the rainy periods, and through the construction of reservoirs for water supply, irrigation and agriculture (Vieira,
Santos, \& Curi, 2010). Such policies resulted in benefits to human populations but had negative impacts on aquatic environments related to changes in water quality, loss of biodiversity, and changes in spatial connectivity between water bodies (Petry, Bayley, \& Markle, 2003).

With river dams construction, areas that had been subjected to seasonal flooding 
disappeared or decreased and may be flooded in different seasons. Such effects had caused the river to become a discontinuous environment and change the physical-chemical composition of the water, structure and functioning of the system, and resulting in a loss of spatial and temporal heterogeneity of the water course (Ward \& Stanford, 1983), and negatively affecting the reproductive processes of fish (Agostinho, Gomes, Suzuki, \& Júlio, 2003). Because of its large home ranges, migratory fishes are particularly affected by reservoir construction (Agostinho, Gomes, \& Pelicice, 2007). The interruption of migration routes, elimination or decrease of spawning and nursery and feeding areas, and effects of genetic isolation in populations, are examples of the negative effects of damming on migratory fish (Agostinho, et al., 2007). However, certain migratory species can maintain viable populations in reservoirs that possess flooding plains and tributaries, without dams upstream from the reservoir (Gubiani, Gomes, Agostinho, \& Okada, 2007).

Specific knowledge on the reproduction and population dynamics is, therefore, necessary to understand and preserve natural fish stocks by means of sustainable utilization. Furthermore, studying these aspects provide important information on possible environmental disturbances, given that fishes ultimately show specific responses to these variations (Montenegro, Torelli, Crispim, \& Medeiros, 2011). The genus Leporinus Spix, 1829 consists of approximately 80 species (Britski, Silimon, \& Lopes, 2007) that present a migratory habit, reproduce during the rainy season, exhibit single-batch synchronous spawning (Tavares \& Godinho, 1994), have a seasonal reproductive strategy (Winemiller, 1998), and demonstrate an omnivorous feeding habit (Gomes \& Verani, 2003). Leporinus piau Fowler, 1941 is a species with wide distribution in the hydrographic basins of the Brazilian semiarid area (Nascimento et al., 2012), and it has ecological importance as a forager fish (Alvim \& Peret, 2004). This species is also important for artisanal, subsistence and sport fishing, and also has great potential for aquaculture (Filho, Nascimento,
Araújo, Barros, \& Chellappa, 2012; Novaes, Freire, Amorim, \& Costa, 2015).

The goal of the present study was to analyze the population structure and reproductive dynamics of $L$. piau by quantifying the abundance, length structure, length-weight relationship, sex ratio, length at first maturity, gonad development stage, gonadosomatic index (GSI), and reproductive stages. Studies of fish species using this approach are important to obtain information that can be used in the development of fishery management policies and species conservation programs. Within this context, the present study was based on the hypothesis that the reproductive period of $L$. piau coincides with the rainy season between February and May, which represents a seasonal reproductive strategy. If this hypothesis is confirmed, the Normative Instruction 209/2008 of the Instituto Brasileiro de Meio Ambiente e Recursos Naturais Renováveis (Brazilian Institute of Environment and Renewable Natural Resources, 2008), which prohibits fishing, transport, commercialization, industrialization and storage of Leporinus species between December 1 and February 28 in rivers and reservoirs of the Brazilian Northeastern area, may be ineffective in its goal of protecting the species during its reproductive and recruiting season.

\section{MATERIAL AND METHODS}

Study site and sampling: The Apodi/ Mossoró River is located in Northeast Brazil and has a length of $210 \mathrm{~km}$ from its source to its mouth at the Atlantic Ocean, and it has an annual flow of approximately 360 million $\mathrm{m}^{3}$ /year (Almeida, Cuellar, Costa, \& Amorim, 2006). This Brazilian region has a semiarid climate and is characterized by high temperatures (annual average of $32.2^{\circ} \mathrm{C}$ ) and a short rainy season between February and May, which presents average annual rainfall amounts of 400-800 mm (Barbosa et al., 2012). The Pau dos Ferros Reservoir is located in the middle stretch of the river $\left(06^{\circ} 08^{\prime} 46^{\prime \prime} \mathrm{S}-38^{\circ} 11^{\prime} 27^{\prime}\right.$ " W), and it was constructed in 1968 for water 
supply and irrigation, and has an area of 11.65 $\mathrm{km}^{2}$ and approximate capacity of 54 million $\mathrm{m}^{3}$ water. This reservoir is currently classified as eutrophic (Moura \& Henry-Silva, 2015).

Samplings were performed quarterly between February 2011 and November 2012 at four points of the reservoir, distributed throughout a longitudinal gradient from dam to the mouth of the rivers in the reservoir (Fig. 1) using gillnets (12 to $70 \mathrm{~mm}$ mesh between adjacent knots) that were set at 17:00 and removed at 5:00 am the following day. The length of the nets was $15 \mathrm{~m}$, the height was between $1.8 \mathrm{~m}$ and $2.0 \mathrm{~m}$, and total area was $301.8 \mathrm{~m}^{2}$. The captured specimens were transported to the laboratory, sorted, identified, separated, and counted. Identifications were confirmed by taxonomists from the Federal University of Paraíba (Universidade Federal da ParaíbaUFPB), and the samples were deposited at the ichthyology collection of the UFPB (catalog UFPB 8968 and 8938). The individual biometric parameters standard length $(\mathrm{cm})$, total weight (g), sex (only the adult individuals for which sex could be confirmed were classified), gonad weight, and macroscopic gonad maturity stage were determined in the laboratory. The gonad maturity stages were classified into three categories adapted of Brown-Peterson, Wyanski, Saborido-Rey, Macewicz and Lowerre-Barbieri (2011): immature, reproductive (developing, spawning capable and regressing) and non-reproductive (regenerating).

Abundance was estimated by calculating the catch per unit effort (CPUE): $\mathrm{CPUE}=\mathrm{N} /$ $\left(\mathrm{m}^{2} \times \mathrm{h}\right)$, where $\mathrm{N}=$ number of individuals captured; $\mathrm{m}^{2}=$ net area $\left(301.8 \mathrm{~m}^{2}\right.$ per site); and $\mathrm{h}=$ exposure time $(12 \mathrm{~h})$. The standard length classes were determined using a frequency histogram with a $5 \mathrm{~cm}$ class interval. The length-weight relationship was calculated using log-transformed data and the following equation (Froese, Tsikliras, \& Stergiou, 2011): $\log \mathrm{Wt}=\mathrm{a}+\mathrm{b} \operatorname{logLp}$, where $\mathrm{Wt}=$ total weight; $\mathrm{Ls}=$ standard length; and ' $a$ ' and ' $b$ ' were constants. The sex ratio was calculated using the absolute frequency by counting the total number of females and males. To determine the length at first maturity $\left(\mathrm{L}_{50}\right)$, the fish were considered "juveniles" (immature stage) or "adults" (developing, spawning capable, regressing and regenerating) and a logistic

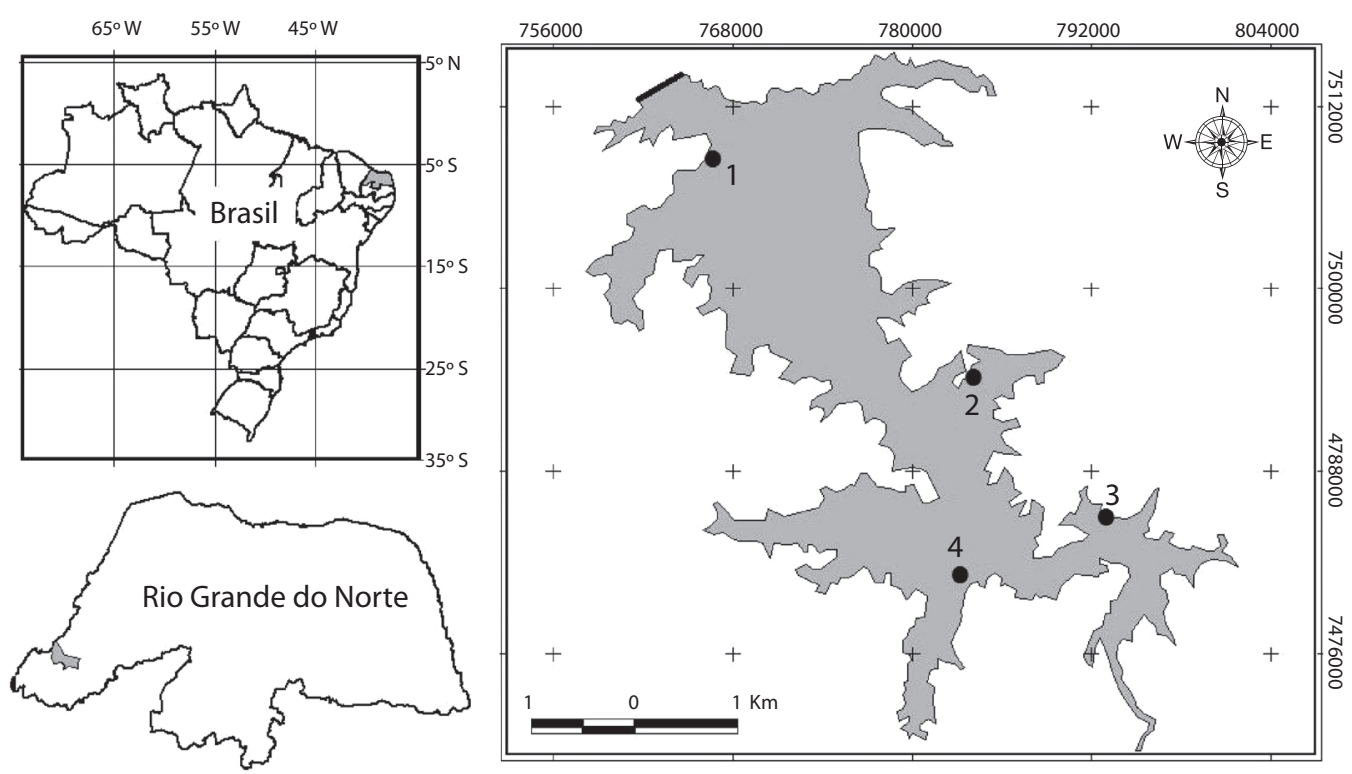

Fig. 1. Location with the sampling points indicated by the numbers 1 through 4, of the Pau dos Ferros Reservoir, Apodi/ Mossoró River, Brazil. 
regression equation was fit using the general linear model (GLM), using the standard length as an independent variable. $\mathrm{P}_{\text {maturity }}=\exp ^{(\mathrm{a}+\mathrm{b}+}$ L) $*\left[1+\exp { }^{(a+b+L)}\right]-1$, where $\mathrm{P}_{\text {maturity }}=$ the estimated proportion of mature individuals in relation to the total length $(\mathrm{L})$. The coefficients were estimated using the iteratively reweighted least squares method (Hüssy, Coad, Farrell, Clausen, \& Clarke, 2012).

The reproductive period was identified based on the temporal distribution of the frequency of reproductive and non-reproductive individuals and the Gonadossomatic index (GSI) monthly average. The GSI was calculated using the following equation: $\mathrm{GSI}=(\mathrm{Wg}$ (Wt)*100, where $\mathrm{Wg}=$ gonad weight; and $\mathrm{Wt}$ $=$ total weight of fish. Rainfall data for the Pau dos Ferros Municipality were obtained from the website of the Empresa de Pesquisa Agropecuária do Rio Grande do Norte (Agricultural Research Company of Rio Grande do Norte, 2015), and the reservoir level data were obtained from the website of the Secretária
Estadual de Meio Ambiente e Recursos Hídri$\cos$ (State Secretary of Environment and Water Resources, 2015; Fig. 2).

Temporal variations of the continuous variables (CPUE and GSI) were analyzed using the non-parametric Kruskal-Wallis $(\mathrm{H})$ test because the variables did not meet the normality assumption even after transformation. Differences in the standard length structure between males and females were tested using the Kolmogorov-Smirnov test. Student's t-test was used to determine whether the $b$ value in the length-weight relationship was equal 3 (isometric growth) (Froese et al., 2011). A chi-squared test $\left(\chi^{2}\right)$ was used to test whether the ratio between males and females was 1:1, and determine whether there were significant differences in the capture of reproductive and non-reproductive individuals over time. Spearman's rank correlation coefficient was used to verify a possible correlation between the GSI and rainfall, CPUE and rainfall, and CPUE and reservoir level. All of the analyses were

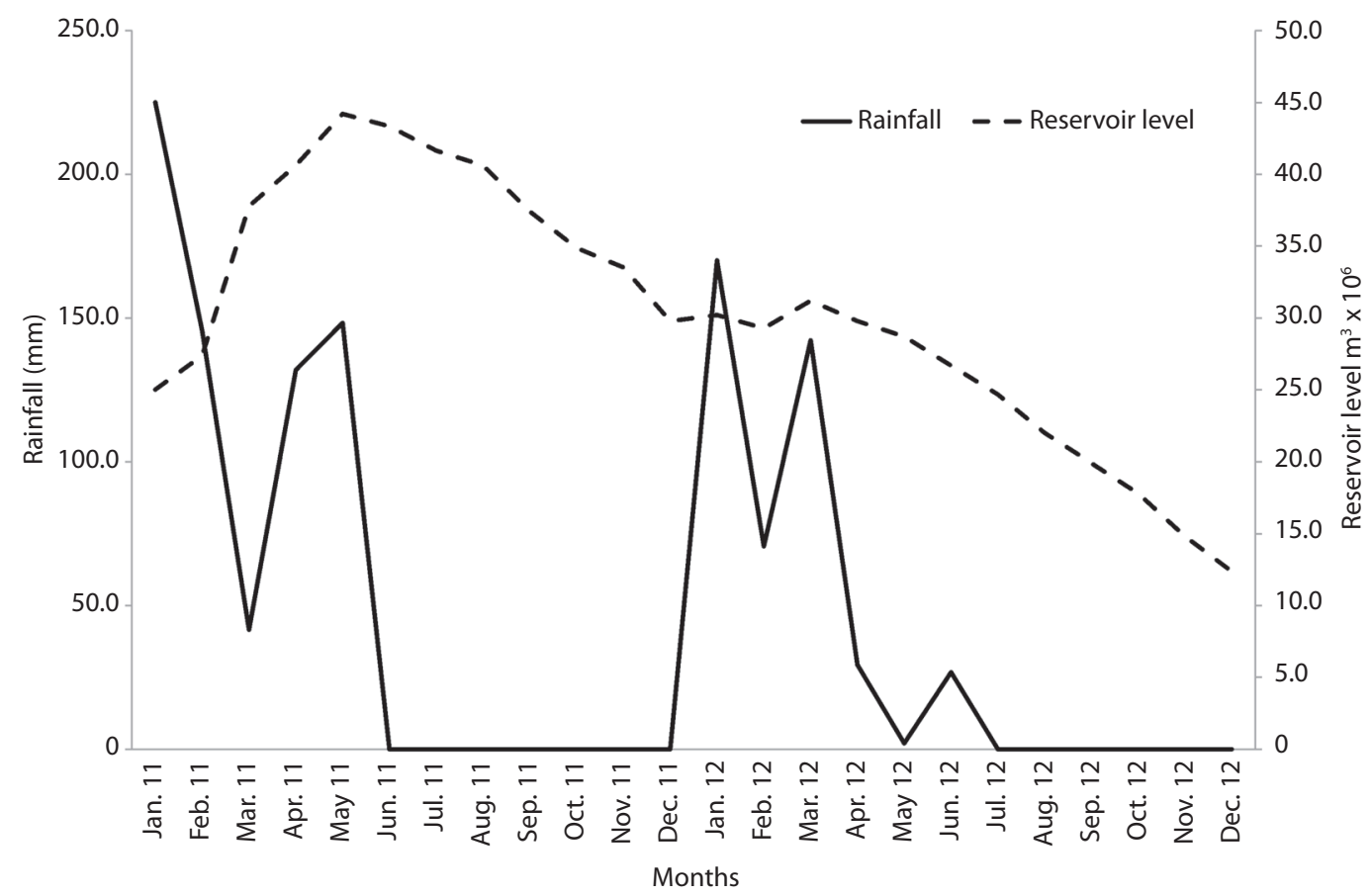

Fig. 2. Monthly rainfall averages for the Pau dos Ferros Municipality and reservoir levels during the study period in the Apodi/Mossoró River, Brazil. 
performed using the software platform R 3.0.2 (R Development Core Team, 2012), with significance measured at $p<0.05$.

\section{RESULTS}

A total of 549 individuals were captured, and the highest abundance was observed in May 2011, with an average CPUE $=0.025955$ $(\mathrm{SD}=0.010328)$ (ind.) $/ \mathrm{m}^{2 *} \mathrm{~h}$, and the lowest abundance was observed in August 2012, with a $\mathrm{CPUE}=0.000759(\mathrm{SD}=0.000472)$ ind./ $\mathrm{m}^{2 *} \mathrm{~h}$. The average CPUE varied significantly between the different months $(\mathrm{H}=20.71 ; p<$ 0.01) (Fig. 3); however, it was not correlated with rainfall ( $\mathrm{rs}=0.15$ and $\mathrm{P}=0.70)$ or the reservoir level ( $\mathrm{rs}=0.23$ and $\mathrm{P}=0.58$ ).

The standard length of the captured individuals varied between $5.9 \mathrm{~cm}$ and $20.7 \mathrm{~cm}$, and the total weight varied between $4.16 \mathrm{~g}$ and $271.5 \mathrm{~g}$. According to the histogram analysis, the $5-10 \mathrm{~cm}$ standard length class presented the highest abundance of juveniles and the $10-15 \mathrm{~cm}$ class the highest abundance of adults (both male and female). Statistical differences were not observed in the standard length structure between males and females $(D=0.1732$; $\mathrm{P}=0.0503$ ) (Fig. 4).

The length-weight relationship was fit by the equation $\log _{10} \mathrm{Wt}=-1.57711+3.00707$ $\log _{10} \operatorname{Ls}\left(\mathrm{r}^{2}=0.9544\right)$, and the $b$ value was statistically equal to $3(\mathrm{t}=0.2510 ; \mathrm{P}=0.801)$, indicating that the species growth was isometric (Fig. 5).

Among the total individuals captured, 319 were juveniles and 230 were adults, of which 148 were males and 82 were females. The sex ratio was 1.8:1 (M:F), and it was significantly different from the expected ratio of $1: 1\left(\chi^{2}=\right.$ $9.0 ; \mathrm{P}<0.05)$. The length at first maturity $\left(\mathrm{L}_{50}\right)$ was estimated at $12.76 \mathrm{~cm}$.

Mature individuals were captured every month except in August 2011 and August 2012. The highest frequencies of reproductive individuals were observed in February (2011: $96.85 \%, \mathrm{n}=31 ; 2012: 79.24 \%, \mathrm{n}=84)$ and May (2011: $87.50 \%, n=7 ; 2012: 63.64 \%, n=$ 9). Non-reproductive individuals predominated

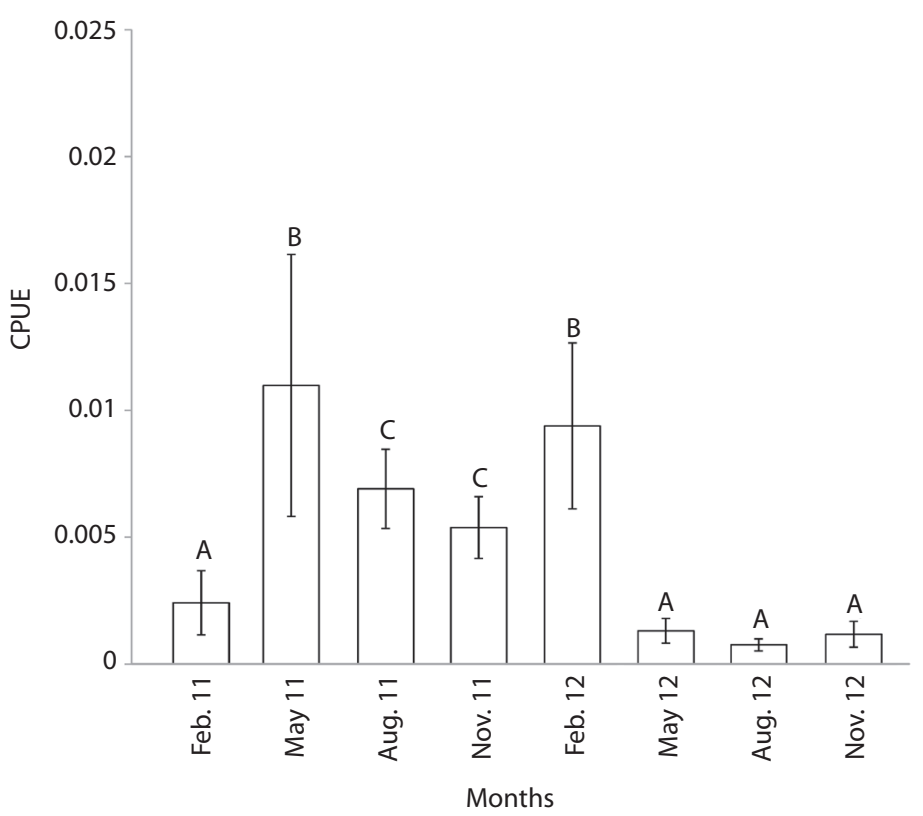

Fig. 3. Monthly average (symbol) and standard error (bar) of the catch per unit effort (CPUE) of Leporinus piau captured at the Pau dos Ferros Reservoir, Apodi/Mossoró River. Different letters indicate statistically significant differences between the average values. 


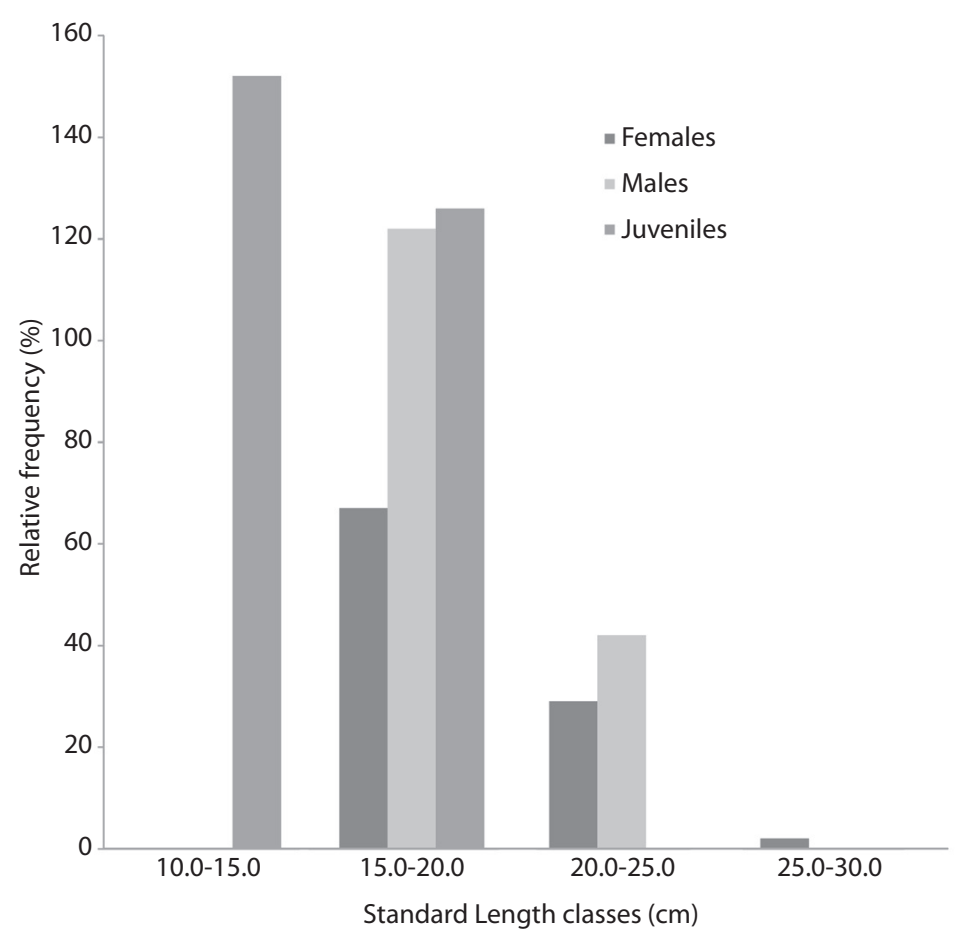

Fig. 4. Distribution frequencies of the standard length classes of females (a), males (b) and juveniles (c) of Leporinus piau captured at the Pau dos Ferros Reservoir, Apodi/Mossoró River, Brazil.

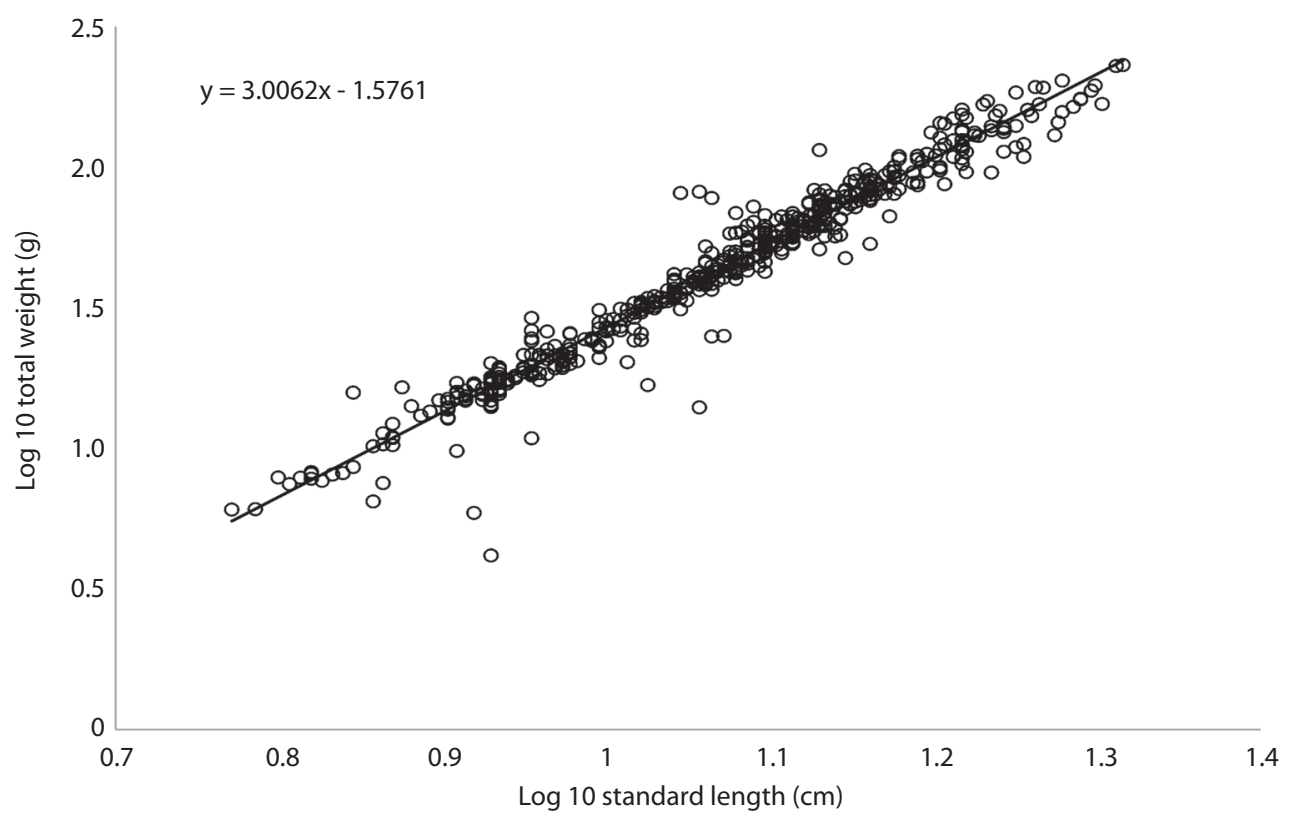

Fig. 5. Length-weight relationship of Leporinus piau captured at the Pau dos Ferros Reservoir, Apodi/Mossoró River, Brazil. 
in August (2011: $100 \%, \mathrm{n}=5 ; 2012: 100 \%, \mathrm{n}=$ 9) and November (2011: $73.30 \%, n=32 ; 2012$ : $61.53 \%, \mathrm{n}=8)$. Significant differences between the stages reproductive and non-reproductive individuals were observed for all months $\left(\chi^{2}\right.$ $>3.84 ; \mathrm{p}<0.05)$ except May and November 2012 (Fig. 6).

For females, the highest average GSI was observed in February (2011: 15.65, $\mathrm{SE}=2.90$; 2012: 10.48, $\mathrm{SE}=3.30)$ and May (2011: 7.68, $\mathrm{SE}=0.26 ; 2012: 2.69, \mathrm{SE}=1.01$ ), and the lowest average GSI was observed in August (2011: 0.39, $\mathrm{SE}=0.06 ; 2012: 0.70, \mathrm{SE}=0.43$ ) and November (2011: 0.84, $\mathrm{SE}=0.38 ; 2012$ : $2.13, \mathrm{SE}=1.70)$. For males, the highest average GSI values were observed in February (2011: 5.72, $\mathrm{SE}=0.88 ; 2012: 4.41, \mathrm{SE}=1.49$ ), and the lowest average GSI values were observed in August (2011: 0.54, $\mathrm{SE}=0.11 ; 2012: 0.23, \mathrm{SE}=$ 0.12 ) and November (2011: 1.64, $\mathrm{SE}=0.56$; 2012: $1.95, \mathrm{SE}=2.15$ ). Statistically significant differences between the monthly GSI averages were observed for males $(\mathrm{H}=40.86 ; \mathrm{P}<0.01)$ and females $(\mathrm{H}=62.66 ; \mathrm{P}<0.01)$ (Fig. 7). The monthly GSI average variation for both males and females coincided with variations in rainfall (Fig. 7), and the Spearman's rank correlation coefficient was significant and positive between rainfall levels and the GSI values for both males $(\mathrm{r}=0.91 ; \mathrm{P}<0.01)$ and females $(\mathrm{r}=$ $0.91 ; \mathrm{P}<0.01)$.

\section{DISCUSSION}

Although abundance was not correlated with rainfall or the reservoir level, higher CPUE values were observed during the months with highest rainfall. In addition, the CPUE was higher in 2011 when the reservoir level was higher relative to the values in 2012 . Rainfall is one of the most important factors affecting the structure of tropical aquatic ecosystems, and differences in the abundance of fish populations between rainy and dry seasons are expected (Lowe-Mcconnell, 1999). The increase in river flow during the rainy season, and also in increased reservoir levels and higher food availability and exploitable habitats, and in larger fish populations in the reservoirs

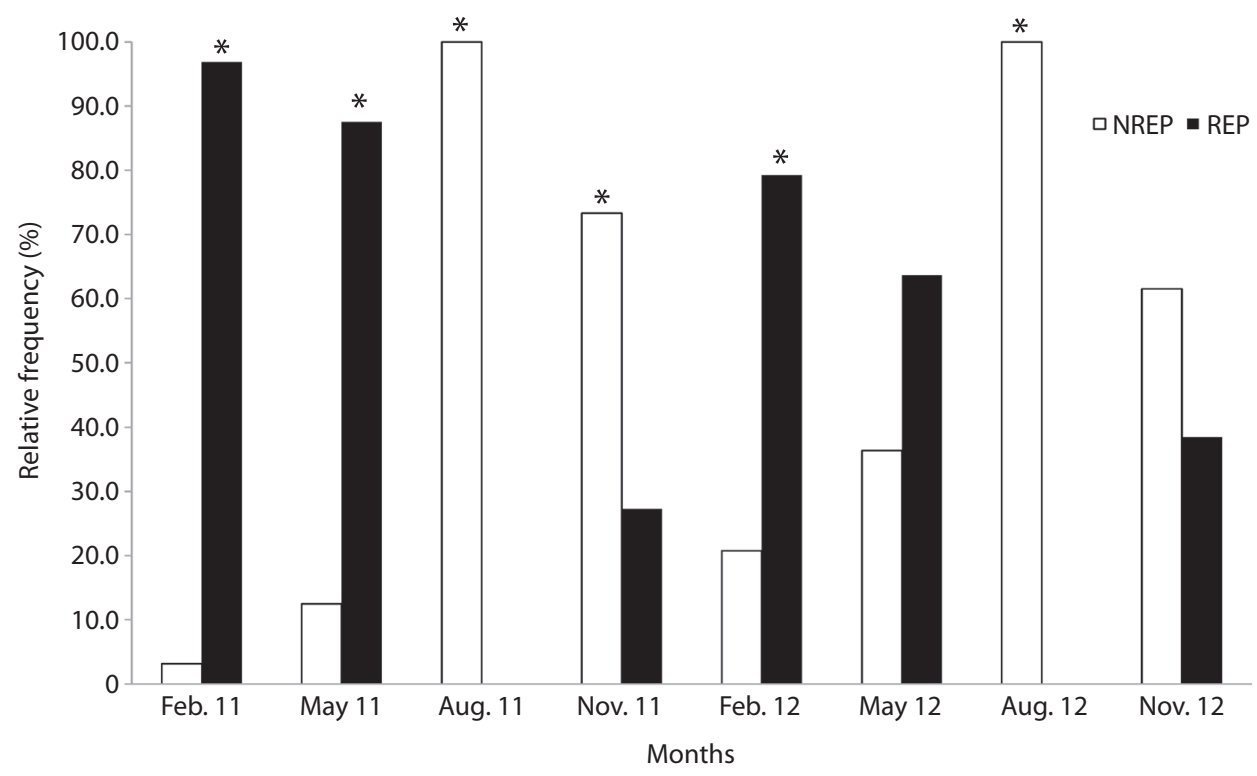

Fig. 6. Relative frequency of the non-reproductive and reproductive individuals over time of Leporinus piau captured at the Pau dos Ferros Reservoir, Apodi/Mossoró River, Brazil. NREP = non-reproductive individuals; REP = reproductive individuals (* Significant difference $\mathrm{p}<0.05$ ). 


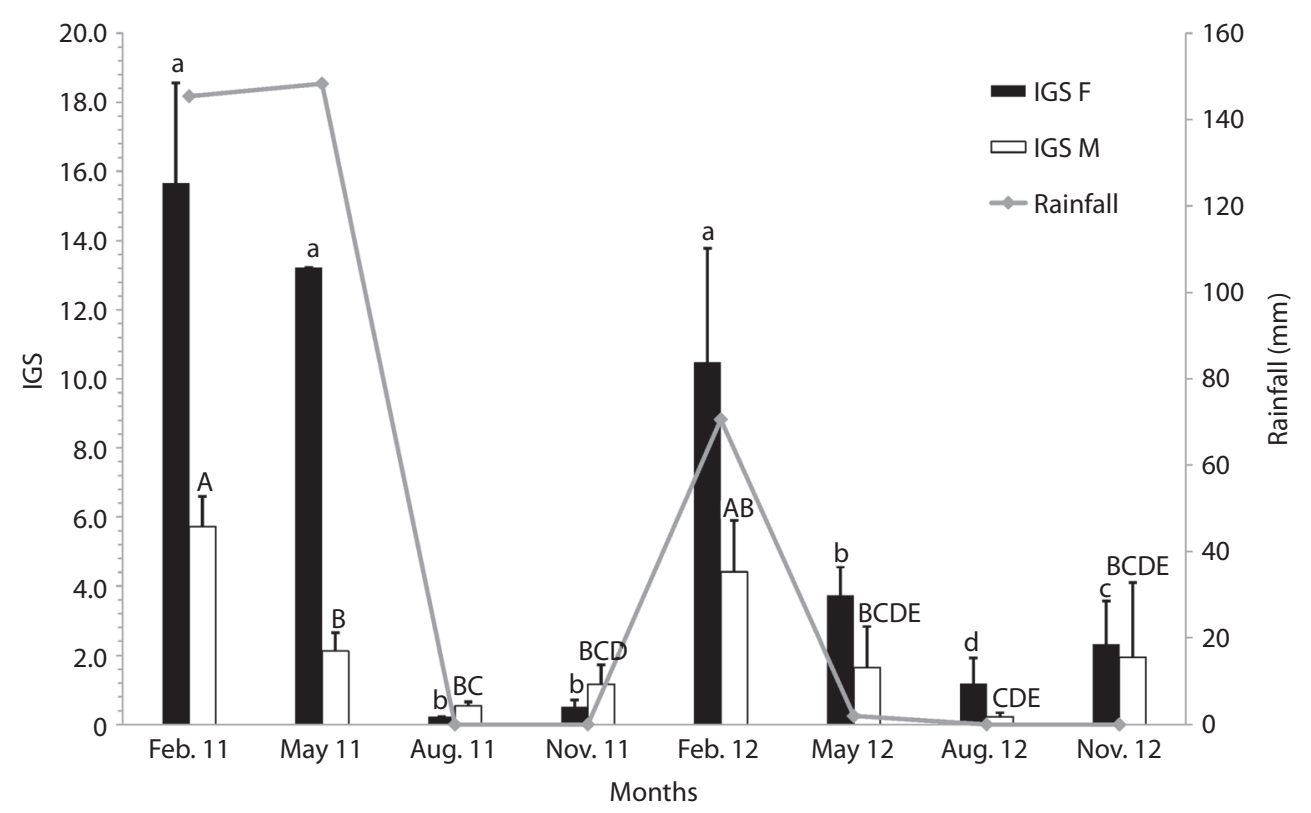

Fig. 7. Monthly average gonadosomatic index (GSI) of the female (IGS F) and male (IGS M) of Leporinus piau captured at the Pau dos Ferros Reservoir, Apodi/Mossoró River, Brazil, and average rainfall during the months of capture. Different lower case letters indicate statistically significant differences among the months for females, and different upper case letters indicate statistically significant differences among the months for males.

(Terra, Santos, \& Araújo, 2010). During the dry season, especially in semiarid regions, there is a strong decrease in the water level of reservoirs, because of high evaporation and water use. The decrease in water volume results in increased water temperature, thermal stratification, increased conductivity, and decreased oxygen concentrations, which may cause mortality and decrease fish population sizes (Bond, Lake, \& Arthington, 2008). These limnological changes may have been more pronounced in 2012 when the reservoir level was relative to 2011 and likely caused a greater decrease in fish abundance. Another factor that may have resulted in the higher capture during the rainy season was the species migratory behavior during the reproductive period, which occurred during the rainy season (see discussion below). During the reproductive period, fish form schools and find shelter, prey, and spawning locations in flooded vegetation, thus becoming more susceptible to capture (Melo, Melo, Faria, Lacerda, \& Silva, 2012).
In studies conducted at the Marechal Dutra Reservoir, Rio Grande do Norte State (RN), the standard length of $L$. piau was observed to vary between $6.15 \mathrm{~cm}$ and $22.0 \mathrm{~cm}$ (Montenegro, Torelli, Araújo Marinho, Crispim, \& Hernandez, 2010) and between $9.6 \mathrm{~cm}$ and $32.9 \mathrm{~cm}$ (Nascimento, Araújo, Chellappa, \& Chellappa, 2013). The maximum length of $L$. piau observed at the Pau dos Ferros Reservoir was lower when compared with data of previous studies. These differences may be related to several factors, particularly the physiology of individuals, which changes depending on environmental factors, food availability and nutritional quality, which affects the growth rate and mortality of the species, as well as the use of different capture equipment (Araya, Agostinho, \& Bechara, 2005). Differences in the length structure between females and males are common in fish populations and reflect growth rate differences between sexes (Sparre \& Venema, 1997). 
These differences have been observed for other species of Leporinus in the Upper Paraná River basin reservoirs, such as Leporinus friderici in the Itaipu and Corumbá reservoirs (Lopes, Benedito-Cecilio, \& Agostinho, 2000), and L. ambryrhynchus in the Miranda Reservoir (Vono, Silva, Maia, \& Godinho, 2002). Significant differences in length structure were not observed between female and male $L$. piau at the Pau dos Ferros Reservoir, indicating that the growth rate was similar for both genders. Environments with a high abundance of juveniles indicated that the species found appropriate locations for the completion of their life cycle, including areas for spawning and larval and juvenile growth, thus enabling new individuals to be constantly recruited to the population (Juza et al., 2014). The abundance of $L$. piau juveniles in the Pau dos Ferros Reservoir was high, suggesting that the population of $L$. piau completes its life cycle in the area of the reservoir and/or in nearby areas.

Several studies have observed allometric growth for the Leporinus species, including the study by Garcia-Ayala, Brambilla, Travassos, Carvalho \& David (2014) for L. spilopleura (Norman 1926), and L. steindachneri (Eigenmann 1907) at the Tucuruí Reservoir, Pará State (PA); the study by Montenegro et al. (2010), who observed negative allometric growth for $L$. piau at the Taperoá II dam in Paraíba State (PB); and the study by Nascimento et al. (2012) and Filho et al. (2012), who observed positive allometric growth for $L$. piau at the Marechal Dutra Reservoir (RN). Only Costa, Andrade, Vidal Junior and Souza (2005) observed isometric growth for L. copelandii (Steindachner 1875) at the Paraíba do Sul River. The isometric growth observed in the present study suggested that this species has been satisfactorily exploiting the food resources available in the reservoir and gaining weight proportional to their growth. Different types of growth may be related to different life strategies developed by different species in their environments because the construction of reservoirs and resulting changes in the ecosystem dynamics affect populations differently (Rêgo, Pinese, Magalhães, \& Pinese, 2008).

Differences in the sex ratio of fish populations may indicate environmental disturbances (Helfman, Bruce, Douglas, \& Brian, 2009). The change of lotic environments (river) into lentic environments (reservoir) causes several disturbances that may affect the sex ratio, and these changes may have caused the differences in sex ratio observed in the present study. However, other factors may be associated with differences in sex ratio, such as differences in behavior and habitat preferences, which may increase the susceptibility of one of the sexes to capture (Casimiro, Garcia, Almeida, \& Orsi, 2011). Therefore, the sexes may have been spatially segregated, with males and females inhabiting different areas of the reservoir, thus resulting in the observed sex ratios. In addition, factors such as differences in the mortality rate, selectivity of the capture equipment, and predatory fishing (affects males and females differently), which also causes deviations from the 1:1 ratio (Garcia, Vieira, Winemiller, \& Raseira, 2004). Among these factors, mortality is considered determinant and may be affected by several factors, such as environmental changes and physicochemical disturbances caused by damming (Lourenço, Mateus, \& Machado, 2008). In the present study, the length at first maturity estimated $(12.76 \mathrm{~cm})$ for $L$. piau was within the range observed for this species in other environments. The length at first maturity has been previously reported to be $8.3 \mathrm{~cm}$ for both females and males in the Ribeirão Jorge Pequeno hydroelectric plant reservoir, Minas Gerais State (MG) (Padilha, Carvalho, Boncompagni-Júnior, Domingos, \& Thomé, 2013) and in the Marechal Dutra Reservoir (RN) was estimated as $17.5 \mathrm{~cm}$ for males and 21.0 $\mathrm{cm}$ for females (Nascimento et al., 2013). The differences observed between different studies may be related to the characteristic environmental conditions of each reservoir (Godinho, 2007), resulting in the adoption of different strategies by the local species (Winemiller, 1989; Orsi, 2010). 
In our study, the highest values of the GSI and frequency of reproductive individuals were observed during the months with the highest rainfall. Therefore, the reproductive period of L. piau was defined between February and May. Filho et al. (2012) and Nascimento et al. (2013) estimated that the reproductive period of L. piau in the reservoir of Marechal Dutra (RN) occurred between April and June. L. friderici in the Upper Paraná River basin presented a reproductive period between October and April (2000), L. reinhardti in the São Francisco River presented a reproductive period between November and February (Weber et al., 2013), and L. muyscorum in the Magdalena River Basin (Colombia) presented a reproductive period between April and June (Jimenez-Segura, Palacio, \& Leite, 2010). In all of these studies, the reproductive period of the Leporinus species occurred during the period of highest rainfall. In general, fish with reproductive migrations reproduce during the rainy season when the conditions are favorable for egg development and provide greater protection against predators and, therefore, lower environmental stress (Lucas \& Baras, 2001; Silva et al., 2015).

It should be noted that upriver from the Pau dos Ferros Reservoir is the Apodi/Mossoró River, which has a well-preserved floodplain area and small tributaries that are free from damming, and provide adequate habitats for the reproduction and development of juveniles from migratory species, such as L. piau (Gubiani et al., 2007). However, studies are required to clearly identify the spawning and nursery areas of this species at the Pau dos Ferros Reservoir. According to the results of the present study, the normative 209/2008 of IBAMA, which prohibits the fishing of L. piau in RN between December 1 and February 28 is endangering the conservation of this species and the maintenance of its stock, because this period does not include the species' reproductive period. Therefore, we recommend that IBAMA should change this normative because our results indicated that the closed season for this species is between February 1 and May
31 ; however, the closed season of other species with rheophilic habits present at this hydrographic basin should be reviewed. We concluded that $L$. piau has an established population in the Pau dos Ferros Reservoir despite certain changes in its population characteristics, such as the sex ratio, and suggest that its reproductive period occurs during the rainy season between January and May, thus indicating a seasonal reproductive strategy and confirming our hypothesis.

\section{ACKNOWLEDGMENTS}

We thank Conselho Nacional de Desenvolvimento Científico e Tecnológico (CNPq), Fundação de Apoio à Pesquisa do Estado do Rio Grande do Norte (FAPERN), Universidade Federal Rural do Semi-Árido (UFERSA), and Programa de Pós-graduação em Ciência Animal (PPCA) for funding this research. We also thank the Fish Ecology Lab and Inland Fisheries team (Laboratório de Ecologia de Peixes e Pesca Continental) (LEPPEC) of the UFERSA for help with all stages of the work.

\section{RESUMEN}

Estructura poblacional y reproducción del pez migratorio Leporinus piau (Characiformes: Anostomidae) en una represa tropical semiárida, Brasil. Los peces migratorios se han visto gravemente afectados por la construcción de embalses y los efectos negativos de estos proyectos, tales como la interrupción de rutas migratorias, reducción o eliminación de desove / áreas de alimentación. El desarrollo inicial puede influir en la estructura de la población de los peces migratorios, lo que resulta en la reducción en la abundancia de los mismos. El Leporinus piau es un pez migratorio que se encuentra ampliamente distribuido en las cuencas del semiárido brasileño y es de importancia para la pesca deportiva y artesanal. El objetivo del estudio fue evaluar la estructura de la población y la dinámica de reproducción de la especie migratoria Leporinus piau en el embalse Pau dos Ferros, región semiárida de Brasil. La relación estructura de tallas y talla-peso de la CPU la talla de la primera la madurez, proporción de sexos, el desarrollo gonadal y el IGS se analizaron. Con redes de enmalle se llevaron a cabo recolecciones trimestralmente entre febrero 2011 y noviembre 2012. Se contaron los peces capturados; se midieron la longitud estándar $(\mathrm{cm})$ y peso total $(\mathrm{g})$, y se disectaron para determinar el estadio 
del sexo y la madurez de las gónadas. Los niveles de agua de lluvia y los embalses se registraron y se analizaron sus correlaciones con el período reproductivo y la CPUE. Un total de 549 individuos fueron capturados. La CPUE promedio varió entre 0.0259 individuos $/ \mathrm{m} 2 * \mathrm{~h}$ (mayo/ 2011) y 0.0008 individuos $/ \mathrm{m} 2 * \mathrm{~h}$ (Agosto/2012), y se observaron diferencias significativas; sin embargo, ninguna correlación significativa se observo entre los niveles de lluvia y el nivel de la represa. La longitud estándar varió entre 5.9 y $20.7 \mathrm{~cm}$, y el peso entre 4.16 y $271.5 \mathrm{~g}$. Un análisis de histogramas, reveló que la clase estándar de $5-10 \mathrm{~cm}$ de longitud fue la más abundante de los jóvenes y que la clase 10-15 cm fue la más abundante de las hembras y machos adultos. La relación peso-talla se ajusta más adecuadamente a la ecuación $\log 10 \mathrm{Wt}=-1.57711+3.00707 \mathrm{Log} 10 \mathrm{Ls}$, donde la especie presenta un crecimiento isométrico. La medida estimada de la primera madurez fue $12.76 \mathrm{~cm}$. Se recogieron un total de 148 machos y 82 hembras (1.81: 1, M: F), y estos valores fueron significativamente diferentes. El más alto GSI se observó en febrero 2011, tanto para las mujeres (10.69) como para hombres (5.72), y el GSI fue significativa y positivamente correlacionado con la precipitación. Se llegó a la conclusión de que la población L. piau está establecida en la represa y encontramos que su periodo de reproducción se produjo durante la época de lluvias entre febrero y mayo.

Palabras clave: represa, periodo reproductivo, talla de la primera madurez, CPUE, conservación, piau.

\section{REFERENCES}

Agostinho, A. A., Gomes, L. C., \& Pelicice, F. M. (2007). Ecologia e Manejo de Recursos Pesqueiros em Reservatórios do Brasil. Maringá: EDUEM.

Agostinho, A. A., Gomes, L. C., Suzuki, H. I., \& Júlio, H. F. (2003). Migratory Fishes of the Upper Paraná River Basin, Brazil. In J. Carolsfeld, B. Harvey, C. Ross, A. Baer (Eds.), Migratory fishes of South America: biology, fisheries and conservation status (pp. 19-98). Ottawa: International Development Centre/ The World Bank.

Almeida, S. A. S., Cuellar, M. Z., Costa, A. M. B., \& Amorim, R. F. (2006). Caracterização das bacias hidrográficas dos rios Apodi/Mossoró e Piranhas/Assu (RN): Mapeamento do uso do solo através das imagens do satélite CBERS 2 e análise socioeconômico. Revista FAPERN, 1(4), 5-9.

Alvim, M. C. C., \& Peret, A. C. (2004). Food resources sustaining the fish fauna in a section of the upper São Francisco River in Três Marias, MG. Brazilian Journal of Biology, 64(2), 195-202. doi: http://dx.doi. org/10.1590/S1519-69842004000200003

Araya, P. R., Agostinho, A. A., \& Bechara, J. A. (2005). The influence of dam construction on a population of
Leporinus obtusidens (Valenciennes, 1847) (Pisces, Anostomidae) in the Yacyreta Reservoir (Argentina). Fisheries Research, 74(1), 198-209. doi:10.1016/j. fishres.2005.02.007

Barbosa, J. E. L., Medeiros, E. S. F., Brasil, J., Cordeiro, R. S., Crispim, M. C. B., \& Henry-Silva, G. G., (2012). Aquatic systems in semi-arid Brazil: limnology and management. Acta Limnologica Brasiliensia, 24(1), 103-118.

Bond, N. R., Lake, P. S., \& Arthington, A. H. (2008). The impacts of drought on freshwater ecosystems: an Australian perspective. Hydrobiologia, 600(1), 3-16. doi: 10.1007/s10750-008-9326-z

Britski, H. A., Silimon, K. Z. S, \& Lopes, B. S. (2007). Peixes do Pantanal: Manual de identificação. Brasília: EMBRAPA-SPI.

Brown-Peterson, N. J., Wyanski, D. M., Saborido-Rey, F., Macewicz, B. J., \& Lowerre-Barbieri, S. K. (2011). A standardized terminology for describing reproductive development in fishes. Marine and Coastal Fisheries, 3(1), 52-70. doi:10.1080/19425120.2011.555724

Casimiro, A. C. R., Garcia, D. A. Z., Almeida, F. S., \& Orsi, M. L. (2011). Reproductive aspects of Moenkhausia intermedia Eigenmann, 1908 (Pisces, Characidae) in the Upper Paraná River Basin, Brazil. ISRN Zoology, 2011, 1-8. doi: http://dx.doi. org/10.5402/2011/802794

Costa, A. P. R., Andrade, D. R. D., Vidal Junior, M. V., \& Souza, G. (2005). Indicators on the reproductive biology of female red-piau in Paraíba do Sul River. Pesquisa Agropecuária Brasileira, 40(8), 789-795. doi: http:// dx.doi.org/10.1590/S0100-204X2005000800009

Empresa de Pesquisa Agropecuária do Rio Grande do Norte. Retrieved on 06/04/2014 from: http://189.124.135.176/monitoramento/monitoramentoboletim1.php.

Filho, J. J. S., Nascimento, W. S., Araújo, A. S., Barros, N. H. C., \& Chellappa, S. (2012). Reprodução do peixe piau preto Leporinus piau (Fowler, 1941) e as variáveis ambientais do açude Marechal Dutra, Rio Grande do Norte. Biota Amazônia, 2(1), 10-21. doi: http://dx.doi.org/10.18561/2179-5746/biotaamazonia.v2n1p10-21

Froese, R., Tsikliras, A. C., \& Stergiou, K. I. (2011). Editorial note on weight-length relations of fishes. Acta Ichthyologica et Piscatoria, 41(4), 261-263. doi: 10.3750/AIP2011.41.4.01

Garcia, A. M., Vieira, J. P., Winemiller, K. O., \& Raseira, M. B. (2004). Reproductive cycle and spatiotemporal variation in abundance of the one-sided livebearer Jenynsia multidentata, in Patos Lagoon, Brazil. Hydrobiologia, 515(1-3), 39-48. doi: http://dx.doi. org/10.1023/B:HYDR.0000027316.59258.a0 
Garcia-Ayala, J. R., Brambilla, E. M., Travassos, F. A., Carvalho, E. D., \& David, G. S. (2014). Lengthweight relationships of 29 fish species from the Tucuruí Reservoir (Tocantins/Araguaia Basin, Brazil). Journal of Applied Ichthyology, 30(5), 1092-1095. doi: 10.1111/jai.12449

Godinho, H. P. (2007). Estratégias reprodutivas de peixes aplicadas à aqüicultura: bases para o desenvolvimento de tecnologias de produção. Revista Brasileira de Reprodução Animal, 31, (3), 351-360.

Gomes, J. H. C., \& Verani, J. R. (2003). Alimentação de espécies de peixes do reservatório de Três Marias. In H. P. Godinho, A. L. Godinho (Eds.), Águas, peixes e pescadores do São Francisco das Minas Gerais (pp.195-227). Belo Horizonte: Pontifícia Universidade Católica Minas.

Gubiani, E. A., Gomes, L. C., Agostinho, A. A., \& Okada, E. K. (2007). Persistence of fish populations in the upper Paraná River: effects of water regulation by dams. Ecology of freshwater fish, 16(2), 191-197. doi: 10.1111/j.1600 0633.2006.00211.x

Helfman, G. S., Collette, B. B., Facey, D. E., \& Bowen, B. W. (2009). The diversity of fish: Biology, Evolution and Ecology. Oxford, England: Wiley-Blackwell.

Hüssy, K., Coad, J. O., Farrell, E. D., Clausen, L. W., \& Clarke, M. W. (2012). Sexual dimorphism in size, age, maturation, and growth characteristics of boarfish (Capros aper) in the Northeast Atlantic. ICES Journal of Marine Science, 69(10), 1729-1735. doi:10.1093/icesjms/fss 156

Instituto Brasileiro do Meio Ambiente e dos Recursos Naturais Renováveis. (25 de novembro de 2008). Instrução Normativa n ${ }^{\circ} 209$. Diário Oficial da União, Brasilia, 87-87.

Jimenez-Segura, L. F., Palacio, J., \& Leite, R. (2010). River flooding and reproduction of migratory fish species in the Magdalena River basin, Colombia. Ecology of Freshwater Fish, 19(2), 178-186. doi: 10.1111/j.1600-0633.2009.00402.x

Juza, T., Vasek, M., Kratochvíl, M., Blabolil, P., Cech, M., Drastík, V., \& Kubecka, J. (2014). Chaos and stability of age-0 fish assemblages in a temperate deep reservoir: unpredictable success and stable habitat use. Hydrobiologia, 724(1), 217-234. doi: 10.1007/ s10750-013-1735-y

Lopes, C. D. A., Benedito-Cecilio, E., \& Agostinho, A. A. (2000). The reproductive strategy of Leporinus friderici (Characiformes, Anostomidae) in the Paraná River basin: the effect of reservoirs. Revista Brasileira de Biologia, 60 (2), 255-266. doi: http://dx.doi. org/10.1590/S0034-71082000000200009

Lourenço, L. D. S., Mateus, L. A., \& Machado, N. G. (2008). Synchrony in the reproduction of Moenkhausia sanctaefilomenae (Steindachner)(Characiformes:
Characidae) in the Cuiabá river floodplain, Pantanal of Mato Grosso, Brazil. Revista Brasileira de Zoologia, 25(1), 20-27. doi: http://dx.doi.org/10.1590/ S0101-81752008000100004

Lowe-Mcconnell, R. H. (1999). Estudos Ecológicos de Peixes Tropicais. São Paulo: Editora da Universidade de São Paulo.

Lucas, M. C., \& Baras, E. (2001). Migration of Freshwater Fishes. Oxford: Blackwell Science.

Melo, T. L., Melo, C. E., Faria, A. A., Lacerda, G. A. F., \& Silva, M. A. (2012). Ocorrência de siluriformes em duas estações sazonais na planície de inundação do baixo rio das mortes, Mato Grosso, Brasil. Revista Eletrônica Interdisciplinar, 2(8), 7-12. Retrieved from: http://www.revista.univar.edu.br/index.php/ interdisciplinar/article/view/73

Montenegro, A. K. A., Torelli, J. E. R., Araújo Marinho, R. S., Crispim, M. C., \& Hernandez, M. I. M. (2010). Aspects of the feeding and population structure of Leporinus piau Fowler, 1941 (Actinopterygii, Characiformes, Anostomidae) of Taperoá II Dam, semi-arid region of Paraíba, Brazil. Biotemas, 23(2), 101-110. doi: http://dx.doi. org/10.5007/2175-7925.2010v23n2p101

Montenegro, A. K. A., Torelli, J. E. R., Crispim, M. C., \& Medeiros, A. M. A. (2011). Population and feeding structure of Steindachnerina notonota Miranda-Ribeiro, 1937 (Actinopterygii, Characiformes, Curimatidae) in Taperoá II dam, semi-arid region of Paraíba, Brazil. Acta Limnologica Brasiliensia, 23(3), 233-244. doi: http://dx.doi.org/10.1590/ S2179-975X2012005000003

Moura, R. S. T., \& Henry-Silva, G. G. (2015). Características limnológicas de uma bacia hidrográfica da região semiárida brasileira. Acta Limnologica Brasiliensia, 27(1), 51-59. doi: http://dx.doi.org/10.1590/ s2179-975x3114

Nascimento, W. S., Araújo, A. S., Barros, N. H. C., Gurgel, L. L., Costa, E. F. S., \& Chellappa, S. (2012). Lengthweight relationship for seven freshwater fish species from Brazil. Journal of Applied Ichthyology, 28(2), 272-274. doi: 10.1111/j.1439-0426.2011.01906.x

Nascimento, W. S., Araújo, A. S., Chellappa, N. T., \& Chellappa, S. (2013). Reproductive strategy of Leporinus piau (Fowler, 1941), a Neotropical freshwater fish from the semi-arid region of Brazil. Journal of Applied Ichthyology, 29(4), 877-880. doi: 10.1111/ jai. 12020

Novaes, J. L. C., Freire, A. E., Abreu Amorim, R. R., \& Costa, R. S. (2015). Diagnóstico da pesca artesanal em um reservatório do semiárido brasileiro. Boletim Instituto da Pesca, São Paulo, 41(1), 31-42.

Orsi, M. L. (2010). Estratégias reprodutivas de peixes: estratégias reprodutivas da região média-baixa do 
rio Paranapanema, reservatório de Capivara. São Paulo: Blucher Acadêmico.

Padilha, G. E. V., Carvalho, J. A. B. A., BoncompagniJúnior, O., Domingos, F. F. T., \& Thomé, R. G. (2013). Length-weight relationship and reproductive activity of the Leporinus piau Fowler, 1941 captured in a small deactivated hydropower plant. Acta Scientiarum Biological Sciences, 35(3), 403-410. doi: 10.4025/actascibiolsci.v35i3.17675

Petry, P., Bayley, P. B., \& Markle, D. F. (2003). Relationships between fish assemblages, macrophytes and environmental gradients in the Amazon River floodplain. Journal of Fish Biology, 63(3), 547-579. doi: 10.1046/j.1095-8649.2003.00169.x

R Development Core Team. (2012). R: A language and environment for statistical computing. R Foundation for statistical computing, Vienna, Austria. Retrieved from http://www.R-project.org.

Rêgo, A. C. L., Pinese, O. P., Magalhães, P. A., \& Pinese, J. F. (2008). Relação peso-comprimento para Prochilodus lineatus (Valenciennes, 1836) e Leporinus friderici (Bloch, 1794) (Characiformes) no reservatório de Nova Ponte-EPDA de Galheiro, rio Araguari, MG. Revista Brasileira de Zoociencias, 10(1), 13-21.

Secretaria do Meio Ambiente e dos Recursos Hídricos. Retrieved from: http://servicos.searh.rn.gov.br/ semarh/sistemadeinformacoes/consulta/cBaciaSitVolumetrica Detalhe.asp?CodigoEstadual $=00$. Acessed in $08 / 03 / \overline{2} 014$

Silva, P. S., Makrakis, M. C., Miranda, L. E., Makrakis, S., Assumpção, L., Paula, S., \& Marques, H. (2015). Importance of reservoir tributaries to spawning of migratory fish in the upper Paraná River. River Research and Applications, 31(3), 313-322. doi: $10.1002 /$ rra.2755

Sparrre, P. \& Venema, S. (1997). Introdução à avaliação de mananciais de peixes tropicais. Parte 1: manual. Roma: FAO.
Tavares, E. F., \& Godinho, H. P. (1994). Ciclo reprodutivo do peixe piau-gordura (Leporinus piau Fowler, 1941) da represa de Três Marias, rio São Francisco. Revista Ceres, 41(233), 28-35.

Terra, B. D. F., Santos, A. B. I. D., \& Araújo, F. G. (2010). Fish assemblage in a dammed tropical river: an analysis along the longitudinal and temporal gradients from river to reservoir. Neotropical Ichthyology, 8(3), 599-606. doi: http://dx.doi.org/10.1590/ S1679-62252010000300004

Vieira, A., Santos, V., \& Curi, W. (2010). Escolha das Regras de Operação Racional para Subsistema de Reservatórios no Semiárido Nordestino. Engenharia Ambiental: Pesquisa e Tecnologia, 7(1), 37-50.

Vono, V., Silva, L. G. M., Maia, B. P., \& Godinho, H. P. (2002). Biologia reprodutiva de três espécies simpátricas de peixes neotropicais: Pimelodus maculatus Lacépede (Siluriformes, Pimelodidae), Leporinus amblyrhynchus Garavello \& Britski e Schizodon nasutus Kner (Characiformes, Anostomidae) do recém-formado Reservatório de Miranda, Alto Paraná. Revista Brasileira de Zoologia, 19(3), 819-826. doi: http:// dx.doi.org/10.1590/S0101-81752002000300020

Ward, J. V., \& Stanford, J. A. (1983). The serial discontinuity concept of lotic ecosystems. In T. D. I. Fontaine III, S. M. Bartell, (Eds.), Dynamics of lotic ecosystems (pp. 29-42). Michigan: Arbor Science.

Weber, A. A., Nunes, D. M. F., Gomes, R. Z., Rizzo, E., Santiago, K. B., \& Bazzoli, N. (2013). Downstream impacts of a dam and influence of a tributary on the reproductive success of Leporinus reinhardti in São Francisco River. Aquatic Biology, 19(2), 195-200. doi: 10.3354/ab00531

Winemiller, K. O. (1989). Patterns of variation in life history among South American fishes in seasonal environments. Oecologia, 81(2), 225-241. 
